\title{
ARTICLE
}

\section{Annual cycle of phytoplankton with emphasis on potentially harmful species in oyster beds of Términos Lagoon, southeastern Gulf of Mexico}

Ciclo anual del fitoplancton con énfasis en las especies potencialmente nocivas en bancos ostrícolas de la laguna de Términos, sureste del Golfo de México

\section{Carlos A. Poot-Delgado ${ }^{1,2,3}$, Yuri B. Okolodkov' ${ }^{1}$, José A. Aké-Castillo ${ }^{1}$ and Jaime Rendón-von Osten ${ }^{4}$}

'Instituto de Ciencias Marinas y Pesquerías, Universidad Veracruzana, Calle Hidalgo No. 617, Col. Rio Jamapa, C.P. 94290, Boca del Rio, Veracruz, México. cpoot@itescham.edu.mx

${ }^{2}$ Centro de Estudios Tecnológicos del Mar, Campeche 02, Km. 1 Carretera Campeche-Hampolol, Col. Palmas C.P. 24027, Campeche, Campeche, México

${ }^{3}$ Instituto Tecnológico Superior de Champotón, Carretera Champotón-Isla Aguada Km. 2, Col. El Arenal, C.P. 24400, Champotón, Campeche, México

${ }^{4}$ Instituto de Ecología, Pesquerías y Oceanografía del Golfo de México, Universidad Autónoma de Campeche, Apdo. Postal 520, C.P. 24030 Campeche, Campeche, México

Resumen.- Para definir la composición de la comunidad fitoplanctónica con énfasis en las especies nocivas en los bancos ostrícolas de la laguna de Términos, SE del Golfo de México, 6 sitios de muestreo fueron monitoreados mensualmente desde agosto 2012 a septiembre 2013. Se midió la temperatura del agua, salinidad, potencial de hidrógeno, saturación de oxígeno, nutrientes inorgánicos y la abundancia de fitoplancton. La temperatura y la salinidad se caracterizaron por diferencias estacionales marcadas. Los valores de pH y saturación de oxígeno sugirieron un predominio de la actividad fotosintética. La comunidad fitoplanctónica se caracterizó por el predominio de nanoflagelados y diatomeas. La abundancia de fitoplancton y su variación estacional presentaron los valores mínimos $\left(10^{3}\right.$ células $\left.\mathrm{L}^{-1}\right)$ durante la época de secas (febrero-mayo) y valores altos $\left(10^{6}\right.$ células $L^{-1}$ ) durante la temporada de lluvias (junio-septiembre). Otra característica importante de la comunidad fitoplanctónica fue la presencia de especies de dinoflagelados nocivos: Akashiwo sanguinea, Karenia cf. mikimotoi, Pyrodinium bahamense var. bahamense, Prorocentrum mexicanum y P. minimum. Las cianobacterias Anabaena y Cylindrospermopsis cuspis alcanzaron abundancias de $1.9 \times 10^{6}$ y $1.3 \times 10^{6}$ células $L^{-1}$, respectivamente. Los géneros Alexandrium y Pseudo-nitzschia estuvieron presentes, pero los taxones no fueron identificados a nivel de especie. En conclusión, la comunidad fitoplanctónica se somete a cambios en la composición de especies y en la estructura de la comunidad durante cada temporada climática, en respuesta a la variación ambiental, que permite el desarrollo de la comunidad fitoplanctónica de acuerdo a las condiciones imperantes.

Palabras clave: Cambios estacionales, cianobacterias, diatomeas, dinoflagelados, lagunas costeras

\begin{abstract}
To define the composition of the phytoplankton community, with an emphasis on harmful species, 6 stations were monitored monthly in the oyster beds of Términos Lagoon, SE Gulf of Mexico, from August 2012 to September 2013. Water temperature, salinity, hydrogen potential, oxygen saturation, inorganic nutrients and abundance of phytoplankton were determined. Temperature and salinity were characterized by marked seasonal differences. The $\mathrm{pH}$ values and the oxygen saturation suggest a predominance of photosynthetic activity. The phytoplankton community was characterized by the dominance of nanoflagellates and diatoms. The abundance and seasonal variation of phytoplankton showed minimum values $\left(10^{3}\right.$ cells $\left.\mathrm{L}^{-1}\right)$ during the dry season (February-May) and high values $\left(10^{6}\right.$ cells $\left.\mathrm{L}^{-1}\right)$ during the rainy season (JuneSeptember). Another significant feature of the phytoplankton community was the presence of the harmful dinoflagellate species Akashiwo sanguinea, Karenia cf. mikimotoi, Pyrodinium bahamense var. bahamense, Prorocentrum mexicanum and P. minimum. The cyanobacteria Anabaena and Cylindrospermopsis cuspis reached abundance of $1.9 \times 10^{6}$ and $1.3 \times 10^{6}$ cells $\mathrm{L}^{-1}$, respectively. The genera Alexandrium and Pseudo-nitzschia were present, but the taxa were not identified to the species level. In conclusion, the phytoplankton community undergoes changes in both species composition and structure of the community during each climatic season, in response to environmental variation, which allows the development of the phytoplankton community according to the conditions.
\end{abstract}

Key words: Seasonal changes, cyanobacteria, diatoms, dinoflagellates, coastal lagoons 


\section{IINTRODUCTION}

The worldwide increase in the occurrence and impact of harmful algal bloom (HABs) events (Anderson et al. 2002) has frequently been attributed to, either directly or indirectly, enhanced cultural eutrophication (Glibert et al. 2005, 2006; GEOHAB 2006, Kudela et al. 2008). Over the past decade, concern has grown over the possible role of toxic or other harmful algae in the increasing number of aquatic animals' health problems detected in several economic activities, such as aquaculture, fisheries and coastal tourism (Hallegraeff 2002, Smayda 2002, Hallegraeff et al. 2003, Landsberg et al. 2006, NúñezVázquez et al. 2011, Phlips \& Badylak 2012). In Mexico, a recent review of the current status of HABs documents an increase in the number of records and reports of harmful algal species (Band-Schmidt et al. 2011).

Términos Lagoon is one of the key ecosystems in the southern Gulf of Mexico and has been the focus of both national and international attention because of its ecological and economic importance and because of the potential impact on this ecosystem exerted by human activities such as urban development, agricultural, oil and gas activities, overfishing, dredging, deforestation and scarcity of freshwater (Yáñez-Arancibia \& Day 2005).

Términos Lagoon is characterized by high primary productivity and it is considered the most important breeding ground for several shrimp and finfish species (García-Ríos et al. 2013); extensive oyster reefs are located near the mouths of rivers flowing into the lagoon, mainly in the areas of brackish water along the fluvial Pom-Atastalagoon system (Fig. 1). This fluvial-lagoon system is connected with Términos Lagoon and it is a storage area; along with freshwater, the fluvial system transports sediment, organic matter, nutrients and organisms to the to the lagoon (Rojas-Galavíz et al. 1990, Bach et al. 2005, Muciño-Márquez et al. 2014).

There are few studies of the phytoplankton community of fluvial-lagoon systems adjacent to Términos Lagoon. Barreiro-Güemes \& Aguirre-León (1999) conducted a study on the spatial-temporal distribution of phytoplankton biomass, reporting an average chlorophyll $a$ concentration of $19.86 \mathrm{mg} \mathrm{m}^{-3}$. Suárez-Caabro \& GómezAguirre (1965) and Gómez-Aguirre (1974) reported the genera Coscinodiscus Ehrenb., Biddulphia S.F. Gray, Chaetoceros Ehrenb., Rhizosolenia Brightw., Nitzschia Hassall, Ceratium Schrank and Protoperidinium Bergh as the main taxonomic groups in Boca Atasta and Boca Chica. Muciño-Márquez et al. (2014) presented the results of a two-day survey in Pom-Atasta and Palizada del Este, in February 2011, recorded that Cylindrotheca closterium was the most abundant species in both systems, with an abundance of $5.3 \times 10^{4}$ cells $\mathrm{L}^{-1}$. Furthermore, in the course of an annual investigation, conducted from July 2012 to May 2013, Poot-Delgado et al. (2013) reported that phytoplankton abundance and seasonal variation showed minimum values $\left(10^{3}\right.$ cells $\left.\mathrm{L}^{-1}\right)$ during the rainy season (July-October) and high values $\left(10^{6}\right.$ cells $\left.\mathrm{L}^{-1}\right)$ during the windy season (November-February). Additionally, the presence of the harmful dinoflagellate species Pyrodinium bahamense var. bahamense, Prorocentrum hoffmanianum, P. mexicanum y P. minimum was noted.

In the present study, unlike in all previous ones performed in Términos Lagoon, we followed seasonal changes in species composition, with an emphasis on major taxonomic groups and potentially harmful species, based on the analysis of monthly samples taken from August 2012 to September 2013. The purpose of this study was to characterize the phytoplankton community and to determine the physical-chemical factors that favor the presence of harmful species throughout an annual cycle.

\section{Material AND MEthods}

The present study was conducted in the areas of extraction of bivalve molluscs in the Lagoon of San Carlos and Puerto Rico subsystem in Términos Lagoon (Fig. 1a), located 30 $\mathrm{km}$ west of Ciudad del Carmen, state of Campeche $\left(18^{\circ} 33\right.$ $\left.38^{\prime} \mathrm{N}, 92^{\circ} 01^{\prime}-14^{\prime} \mathrm{W}\right)$. The area is characterized by 3 meteorological seasons: dry from February to May, rainy from June to September and windy from October to January (Yáñez-Arancibia \& Day 1988, Ramos-Miranda et al. 2006). Monthly sampling was performed in 6 oyster banks (2-m depth), from August 2012 to September 2013 (Fig. 1b).

At each site, surface seawater samples were collected with a plastic bottle; an aliquot of $100 \mathrm{ml}$ was used to analyze cell abundances for phytoplankton taxa (Lindahl 1986). Samples were fixed in situ with an alkaline solution of iodine (Utermöhl 1958) and subsequently preserved by adding 4\% neutralized formalin (Throndsen 1978). Additionally, circular horizontal tows were performed for 5 min with a conical hand net, $20 \mu \mathrm{m}$ mesh size, at each sampling site. The collected material was placed in glass vials and fixed using the same procedure as for the quantitative analysis to identify the phytoplankton taxa. In situ temperature $\left({ }^{\circ} \mathrm{C}\right)$, salinity, $\mathrm{pH}$ and oxygen saturation 

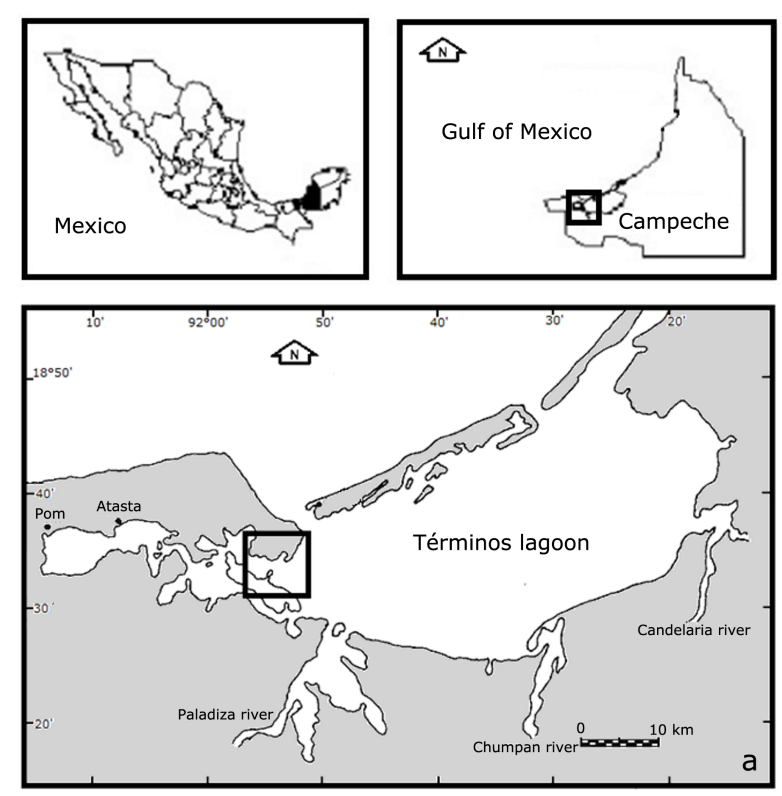

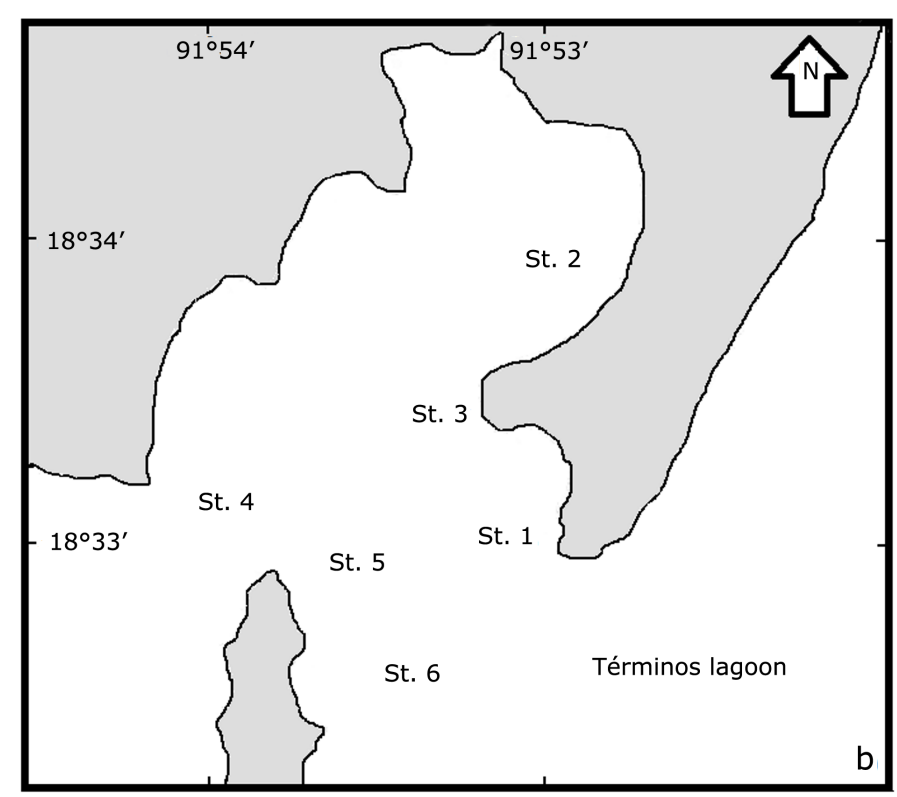

Figure 1. a) Study area and b) location of sampling stations / a) Zona de estudio y b) localización de las estaciones de muestreo

(\%) were measured on-board using a HANNA Multiparameter probe, model HI9828, with sensor model HI769828 and a HACH Multiparameter probe, model HQ40d (HANNA Instruments Inc., Woonsocket, Rhode Island, USA). Orthophosphate ( $\left.\mathrm{P}_{-} \mathrm{PO}_{4}{ }^{3-}\right)$, ammonium $(\mathrm{N}-$ $\left.\mathrm{NH}_{4}^{+}\right)$, nitrite $\left(\mathrm{N}-\mathrm{NO}_{2}{ }^{-}\right)$, nitrate $\left(\mathrm{N}-\mathrm{NO}_{3}{ }^{-}\right)$and silicate $(\mathrm{Si}-$ $\mathrm{SiO}_{2}^{4-}$ ) analyses were performed following Strickland \& Parsons (1972).

Identification and quantification of phytoplankton cells were performed according to the Utermöhl technique (Utermöhl 1958), taking $10 \mathrm{~cm}^{3}$ of a sample and using inverted microscope Carl Zeiss Axio Observer.A1 equipped with phase contrast objectives $(10 \mathrm{x} / 0.25 \mathrm{Ph} 1$ ADL and LD 20x/0.30 Ph1). Nanoflagellates $(<20 \mu \mathrm{m})$, due to their small size, were not identified to species level, nor were autotrophic and heterotrophic nanoflagellates distinguished. Abundance values were expressed as cells $\mathrm{L}^{-1}$. Observation and identification of phytoplankton species were performed on fixed samples with a Motic compound microscope equipped with planachromatic objectives $4 \mathrm{x} / 0.10,10 \mathrm{x} / 0.25,20 \mathrm{x} / 0.40,40 \mathrm{x} / 0.65$ and $100 \mathrm{x} /$ 1.25 , using specialized taxonomic literature.

The hypothesis of differences among months and among sampling stations was tested by analysis of variance, and Tukey TSD (Truly Significant Difference) was applied with a significance level of 0.05 (Daniel 1993).
The normality of the recorded data was assessed by the Kolmogorov-Smirnov test and homoscedasticity with the Bartlett's test (Garson 2012). The calculation routine was performed with Statgraphics Centurion XV program, version 18.2.06.

To determine the main environmental factors affecting the distribution patterns of phytoplankton groups of species in the oyster banks, canonical correspondence analysis (CCA) was performed using a matrix of environmental factors and abundances of species (Ter Braak 1986). Data were transformed to $\log _{10}($ data +1$)$ before analysis, because 1) data did not follow a normal distribution, and 2) a large difference in magnitude between the values of biological and physical-chemical data occurred. The significance of the axes of the CCA was tested using a Monte Carlo analysis with 199 permutations. The calculation routine was performed using the CANOCO program, version 201.4.56.

\section{Results}

\section{Temperature, SALINITY, OXYGEN SATURATION AND PH}

Temperature in the study area showed a range of temporal variability of $\pm 3^{\circ} \mathrm{C}$. Minimum average values $\left(26.8-27.3^{\circ} \mathrm{C}\right)$ were recorded during the windy season and maximum average values $\left(29.7-30.6^{\circ} \mathrm{C}\right)$ during the rainy season 
(Table 1). Salinity minimum average values were measured in the windy season (6.1-8.7), and maximum average values during the dry season, with a range of 17.4-19.5 (Table 1). For the $\mathrm{pH}$, minimum mean values were observed during the dry and rainy seasons (7.1-7.6), while the maximum mean was registered during the windy season, with a range of 7.9-8.4 (Table 1). Minimum average oxygen saturation values were recorded in the rainy season (88.4$96.3 \%$ ), while maximum average values (106.2-118.2\%) were observed in the dry season (Table 1). All the variables mentioned above showed significant differences among seasons $(P<0.05)$.

\section{Nutrients}

Variations in the concentrations of the inorganic nutrients were relatively wide as shown in Table 1. Average concentrations of nitrite $\left(\mathrm{N}-\mathrm{NO}_{2}{ }^{-}\right)$and nitrate $\left(\mathrm{N}^{-} \mathrm{NO}_{3}{ }^{-}\right)$were low throughout the study compared to ammonium. However, nitrite concentrations showed maximum values, ranging 0.30-3.40 $\mu \mathrm{mol} \mathrm{L}^{-1}$ in the rainy season (Table 1). Nitrate concentrations showed maximum values, ranging from 1.31 to $3.42 \mu \mathrm{mol} \mathrm{L}^{-1}$ in the rainy season and minimum values $\left(0.54-1.28 \mu \mathrm{mol} \mathrm{L}^{-1}\right)$ in the dry season (Table 1). Ammonium $\left(\mathrm{N}^{-} \mathrm{NH}_{4}^{+}\right)$concentrations were observed in the dry season (1.62-2.05 $\left.\mu \mathrm{mol} \mathrm{L}^{-1}\right)$, while maximum (2.80-3.64 $\mu$ mol $\mathrm{L}^{-1}$ ) were observed in the windy season (Table 1). Orthophosphate $\left(\mathrm{P}_{-} \mathrm{PO}_{4}^{3-}\right)$ concentrations showed minimum average values $\left(0.14-0.60 \mu \mathrm{mol} \mathrm{L}^{-1}\right)$ during the rainy season, while maximum average values $(0.73-1.52 \mu \mathrm{mol}$ $\mathrm{L}^{-1}$ ) were registered during the dry season (Table 1). Silicate $\left(\mathrm{Si}-\mathrm{SiO}_{2}{ }^{4-}\right)$ levels showed maximum mean values (9.05-35.91 $\left.\mu \mathrm{mol} \mathrm{\textrm {L } ^ { - 1 }}\right)$ in the windy season, while minimum mean values (6.48-18.81 $\mu \mathrm{mol} \mathrm{L}^{-1}$ ) were measured in the dry season (Table 1). All the variables mentioned above showed significant differences between seasons $(P<0.05)$.

\section{COMMUNITY COMPOSITION OF PHYTOPLANKTON}

In total, 114 species were identified, of which $52(46 \%)$ were diatoms, $34(30 \%)$ dinoflagellates, 14 (12\%) cyanobacteria, 10 (8\%) nanoflagellates and $4(4 \%)$ silicoflagellates. The total average phytoplankton abundance was $2.4 \times 10^{5}$ cells $\mathrm{L}^{-1}$, with a minimum value of $1.4 \times 10^{5}$ cells $\mathrm{L}^{-1}$ and a maximum of $8.6 \times 10^{6}$ cells $\mathrm{L}^{-1}$. Nanoflagellates ( 5 to $19 \mu \mathrm{m}$ in size) were the most abundant taxa. Nanoflagellates varied slightly in abundance, decreasing in the dry season and increasing in the rainy season. Diatoms, cyanobacteria and dinoflagellates were observed as minor components (Fig. 2).

Table 1. Summarized statistics (for a meteorological season) of environmental variables and nutrients from 6 sampling sites in the oyster beds of Términos Lagoon, Campeche, M exico, in 2012-2013 (mean, range and standard deviation) / Resumen estadístico por estación climática de los variables ambientales y nutrientes en 6 sitios de muestreo en los bancos ostrícolas de la laguna de Términos, Campeche, México, en 2012-2013 (media, rango y desviación estándar)

\begin{tabular}{|c|c|c|c|c|c|c|c|c|c|}
\hline \multirow{2}{*}{ Season } & \multicolumn{4}{|c|}{ Environmental variables } & \multicolumn{5}{|c|}{ Nutrients $\left(\mu \mathrm{mol} \mathrm{L}^{-1}\right)$} \\
\hline & $\mathrm{T}^{\circ} \mathrm{C}$ & Salinity & $\mathrm{pH}$ & D.O (\%) & Nitrite & Nitrate & Ammonia & Phosphate & Silicate \\
\hline \multirow{3}{*}{ Rainy } & 30.2 & 13.2 & 7.6 & 93.2 & 0.97 & 2.20 & 2.10 & 0.30 & 38.21 \\
\hline & $29.7-30.6$ & $11.6-14.3$ & 7.4-7.8 & $88.4-96.3$ & $0.30-3.40$ & $1.31-3.42$ & $1.15-3.79$ & $0.14-0.60$ & $\begin{array}{c}29.50- \\
51.52\end{array}$ \\
\hline & \pm 0.37 & \pm 0.15 & \pm 0.15 & \pm 2.82 & \pm 1.26 & \pm 0.83 & \pm 1.12 & \pm 0.18 & \pm 8.65 \\
\hline \multirow{3}{*}{ Windy } & 27.0 & 7.4 & 8.2 & 104.6 & 0.58 & 1.09 & 3.16 & 0.38 & 22.22 \\
\hline & $26.8-27.3$ & $6.1-8.7$ & $7.9-8.4$ & $98.9-111.8$ & $\begin{array}{l}0.04- \\
3.39\end{array}$ & $\begin{array}{l}0.47- \\
2.26\end{array}$ & $\begin{array}{l}2.80- \\
3.64\end{array}$ & $\begin{array}{c}0.20- \\
0.63\end{array}$ & $\begin{array}{l}9.05- \\
35.91\end{array}$ \\
\hline & \pm 0.19 & \pm 1.12 & \pm 0.18 & \pm 4.73 & \pm 1.24 & \pm 0.70 & \pm 0.31 & \pm 0.17 & \pm 10.00 \\
\hline \multirow{3}{*}{ Dry } & 28.0 & 18.4 & 7.1 & 112.2 & 0.17 & 0.78 & 1.80 & 1.05 & 11.61 \\
\hline & $27.8-28.4$ & $17.4-19.5$ & $6.9-7.3$ & $\begin{array}{l}106.2- \\
118.2\end{array}$ & $\begin{array}{l}0.07- \\
0.35\end{array}$ & $\begin{array}{c}0.54- \\
1.28\end{array}$ & $\begin{array}{l}1.62- \\
2.05\end{array}$ & $\begin{array}{l}0.73- \\
1.52\end{array}$ & $\begin{array}{l}6.48- \\
18.81\end{array}$ \\
\hline & \pm 0.25 & \pm 0.13 & \pm 0.13 & \pm 5.03 & \pm 0.09 & \pm 0.28 & \pm 0.19 & \pm 0.30 & \pm 5.14 \\
\hline $\begin{array}{l}\mathrm{SD} \div \\
\text { season }\end{array}$ & $\begin{array}{c}\mathrm{F}= \\
260.1 *\end{array}$ & $\begin{array}{c}\mathrm{F}= \\
225.1^{*}\end{array}$ & $\mathrm{~F}=64.8^{*}$ & $\mathrm{~F}=44.5^{*}$ & $\mathrm{~F}=53.3^{*}$ & $\mathrm{~F}=11.9^{*}$ & $\mathrm{~F}=6.5^{*}$ & $\mathrm{~F}=15.2^{*}$ & $\mathrm{~F}=8.5^{*}$ \\
\hline
\end{tabular}

*Significant differences SD $(P<0.05$, ANOVA nonparametric one-way) between the seasons 

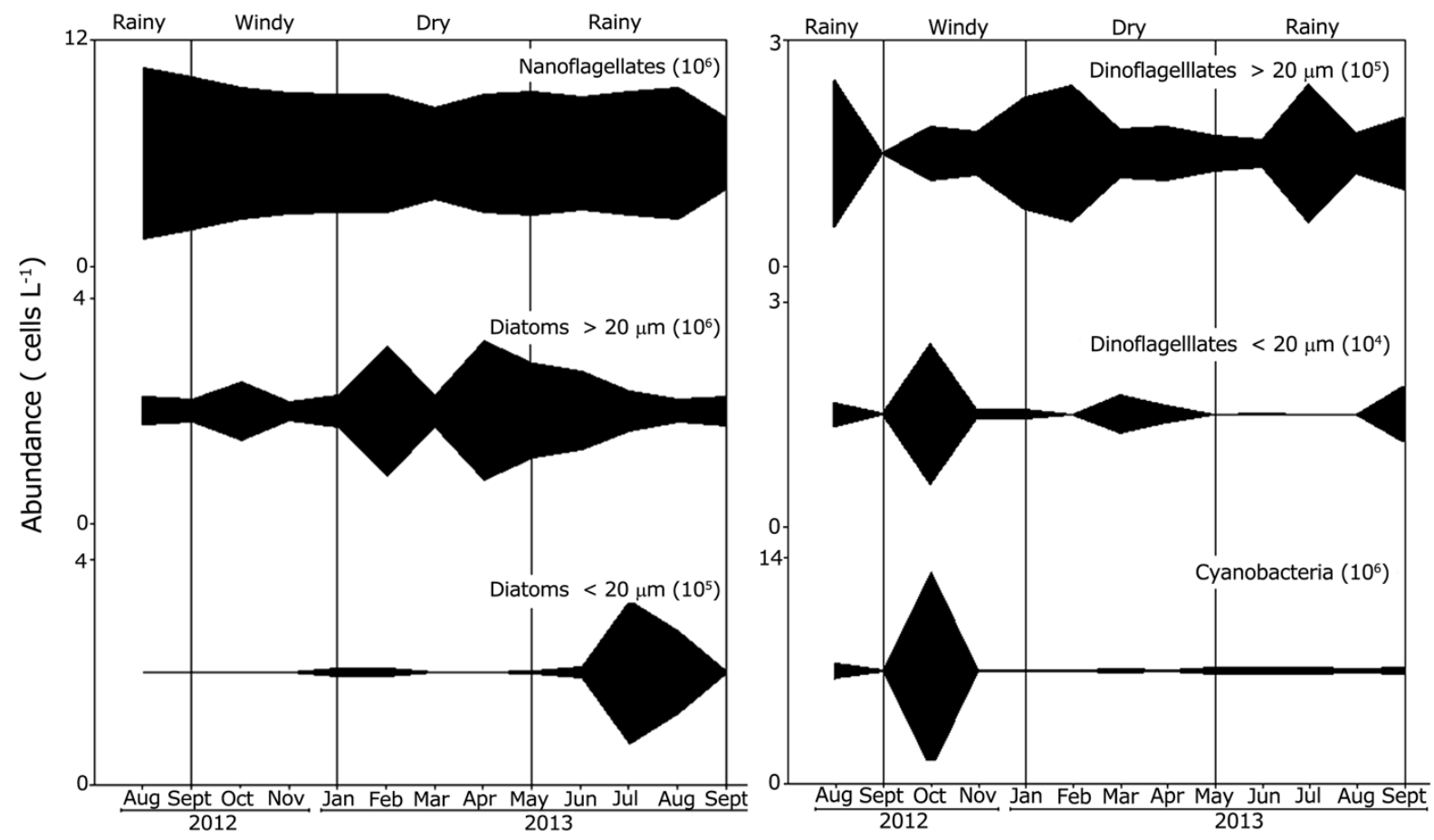

Figure 2. Temporal variation of abundances of major phytoplankton groups in the oyster beds of Términos Lagoon, Campeche, Mexico, in 20122013 / Variación temporal de la abundancia de los principales grupos taxonómicos del fitoplancton en los bancos ostrícolas de la laguna de Términos, Campeche, México, en 2012-2013

The highest abundances of diatoms $>20 \mu \mathrm{m}$ were observed in the dry season; abundances declined in the rainy season. Diatoms $<20 \mu \mathrm{m}$ were markedly present in the rainy season (Fig. 2). The genus Pseudo-nitzschia reached abundances of $1.7 \times 10^{5}$ to $5.0 \times 10^{5}$ cells $\mathrm{L}^{-1}$ and was present throughout the study period, with an average abundance of $3.3 \times 10^{5}$ cells $\mathrm{L}^{-1}$ in the windy and dry seasons (Table 2, Fig. 3b). Cylindrotheca closterium showed high abundances of $1.2 \times 10^{6}$ and $3.5 \times 10^{5}$ cells $\mathrm{L}^{-1}$ during the rainy and windy seasons, respectively, being a species of rapid growth (Table 2, Fig. 3a). Thalassiosira sp. showed a maximum abundance of $1.5 \times 10^{6}$ cells $\mathrm{L}^{-1}$ during the rainy season, while Rhizosolenia setigera and Skeletonema costatum showed maximum abundances of $1.4 \times 10^{4}$ and $8.0 \times 10^{5}$ cells $\mathrm{L}^{-1}$ during the windy season, respectively (Table 2 ).

Dinoflagellates $>20 \mu \mathrm{m}$ showed total abundances one order of magnitude lower $\left(10^{5}\right.$ cells $\left.\mathrm{L}^{-1}\right)$ than that of diatoms in both the rainy (July-August) and dry seasons (FebruaryMay). During the windy season (September-January) the lowest cell abundances were observed. The highest abundance of dinoflagellates $<20 \mu \mathrm{m}$ (up to $10^{4}$ cells $\mathrm{L}^{-1}$ ) was observed in the windy season (January-February), showing two small peaks in the dry and rainy seasons (Fig. 2). Among dinoflagellates, Prorocentrum minimum showed its maximum abundance in the windy season with a value of $6.9 \times 10^{4}$ cells $L^{-1}$ (Table 2, Fig. 3i). Prorocentrum mexicanum abundances averaged $2.0 \times 10^{4}$ cells $\mathrm{L}^{-1}$ in the windy season with a maximum of $4.0 \times 10^{4}$ cells $\mathrm{L}^{-1}$ in the rainy seasons (Table 2, Fig. 3j). Peridinium quinquecorne was found in the rainy season with an abundance of $2.1 \times 10^{5}$ cells $\mathrm{L}^{-1}$ and varied in abundance throughout the dry and windy seasons (Table 2, Fig. 3h). The genus Alexandrium Halim that includes toxic representatives showed maximum abundances of $1.6 \times 10^{4}$ cells $\mathrm{L}^{-1}$ in the windy season, and $1.1 \times 10^{4}$ cells $\mathrm{L}^{-1}$ in the dry season, with an average value of $1.0 \times 10^{4}$ cells $\mathrm{L}^{-1}$ (Table 2, Fig. 3d). The Gymnodiniales gen. spp., including Akashiwo sanguinea showed higher abundances of $6.0 \times 10^{4}$ cells $\mathrm{L}^{-1}$ in the windy season; however, A. sanguinea was also observed in the rainy and dry seasons with a maximum abundance of $3.7 \times 10^{4}$ and $4.9 \times 10^{4}$ cells $\mathrm{L}^{-1}$, respectively (Table 2, Fig. 3e). Gymnodinium cf. catenatum showed high abundances of $9.5 \times 10^{4}$ cells $\mathrm{L}^{-1}$ in the rainy season and was also present in the windy and dry seasons, with values of $5.0 \times 10^{3}$ and $3.9 \times 10^{4}$ cells $\mathrm{L}^{-1}$, respectively (Table 2 , Fig. $3 \mathrm{f}$ ). As an 
Table 2. List of potentially harmful species (HAB) observed from 6 sampling sites in the oyster beds of Términos Lagoon, Campeche, Mexico, in 2012-2013. The taxonomic group (Tax Group) is indicated: diatoms (DIA), dinoflagellates (DIN), and cyanobacteria (CYA) / Lista de especies potencialmente nocivas (FAN) observadas en 6 sitios de muestreo en los bancos ostrícolas de la laguna de Términos, Campeche, México, en 2012-2013. Grupo taxonómico (Grupo Taxonómico) se indica: dinoflagelados (DIN), diatomeas (DIA) y cianobacterias (CYA)

\begin{tabular}{|c|c|c|c|c|}
\hline \multirow{2}{*}{ Species } & \multirow{2}{*}{ Tax Group } & Rainy & Windy & Dry \\
\hline & & \multicolumn{3}{|c|}{ Maximum abundances (cells L ${ }^{-1}$ ) } \\
\hline \multicolumn{5}{|l|}{ Human potentially toxic species ${ }^{1}$} \\
\hline Alexandrium sp. & DIN & 11,000 & 16,000 & 5,000 \\
\hline Gymnodinium cf. catenatum Graham & DIN & 95,000 & 39,000 & 5,000 \\
\hline Pyrodinium bahamense Plate var. bahamense & DIN & 6,000 & 3,000 & 3,000 \\
\hline \multicolumn{5}{|l|}{ Amnesic Shellfish Poisoning (ASP) } \\
\hline \multicolumn{5}{|l|}{ Neurotoxic (NTX, mouse assay) $)^{2}$} \\
\hline $\begin{array}{l}\text { Prorocentrum hoffmannianum Faust } \\
\text { Prorocentrum minimum (Pavillard) J. Schiller }\end{array}$ & $\begin{array}{l}\text { DIN } \\
\text { DIN }\end{array}$ & $\begin{array}{r}2,000 \\
30,000\end{array}$ & 69,000 & 26,000 \\
\hline $\begin{array}{l}\text { Microcystin LR and lipopolysaccharide (LPS) }{ }^{3} \\
\text { Merismopedia } \mathrm{sp} . \\
\text { Oscillatoria } \mathrm{sp} .\end{array}$ & $\begin{array}{l}\text { CYA } \\
\text { CYA }\end{array}$ & $\begin{array}{l}33,000 \\
83,000\end{array}$ & $\begin{array}{l}106,000 \\
258,000\end{array}$ & 195,000 \\
\hline \multicolumn{5}{|l|}{$\begin{array}{l}\text { Microcystin, anatoxin-a, anatoxin-a (S), saxitoxin and } \\
\text { lipopolysaccharide (LPS) }\end{array}$} \\
\hline Anabaena sp. & CYA & $1,941,000$ & 36,000 & 485,000 \\
\hline \multicolumn{5}{|l|}{$\begin{array}{l}\text { Microcystin LR cylindrospermopsin, saxitoxin, neusaxitoxin } \\
\text { and neosaxitoxin } \\
3\end{array}$} \\
\hline \multicolumn{5}{|l|}{ Potentially fish-killing species ${ }^{4}$} \\
\hline $\begin{array}{l}\text { Karenia cf. mikimotoi (Miyake \& Kominami ex Oda) G. } \\
\text { Hansen \& Ø.Moestrup }\end{array}$ & DIN & 1,000 & - & 9,000 \\
\hline Prorocentrum mexicanum B. F. Osorio & DIN & 40,000 & 20,000 & 32,000 \\
\hline Skeletonema costatum (Grev.) Cleve & DIA & - & 80,000 & 35,000 \\
\hline Thalassiosira sp. & DIA & $1,591,000$ & - & 15,000 \\
\hline \multicolumn{5}{|l|}{ Potentially bloom-forming species ${ }^{5}$} \\
\hline $\begin{array}{l}\text { Akashiwo sanguinea (K.Hirasaka) G.Hansen \& } \\
\text { Ø.Moestrup }\end{array}$ & DIN & 37,000 & 60,000 & 49,000 \\
\hline Cylindrotheca closterium Ehrenberg. & DIA & $1,241,000$ & 356,000 & $1,689,000$ \\
\hline Peridinium quinquecorne T.H. Abé & DIN & 210,000 & 1,000 & - \\
\hline Rhizosolenia setigera Brightw. & DIA & 9,000 & 14,000 & 11,000 \\
\hline
\end{tabular}

\footnotetext{
${ }^{1}$ Known species that are potentially toxic: PSP, DSP, ASP, NTX (IOC 2002)

${ }^{2}$ Responsible for mouse mortality via a water-soluble toxin. However, there are no data indicating impacts to human consumers (Grzebyk et al. 1997)

${ }^{3}$ Known species that are potentially toxic: Microcystin LR, lipopolysaccharide (LPS), microcystin, anatoxin-a, anatoxin-a (S), saxitoxin, cylindrospermopsin, neusaxitoxin and neosaxitoxin (UNESCO 2009)

${ }^{4}$ Those species that are known or suspected to cause fish losses in mariculture (Anderson et al. 2001)

${ }^{5}$ Those species that are known to produce blooms elsewhere (Anderson et al. 2001) or that occasionally reached abundances exceeding $10^{6}$ cells $\mathrm{L}^{-1}$ in our samples
} 

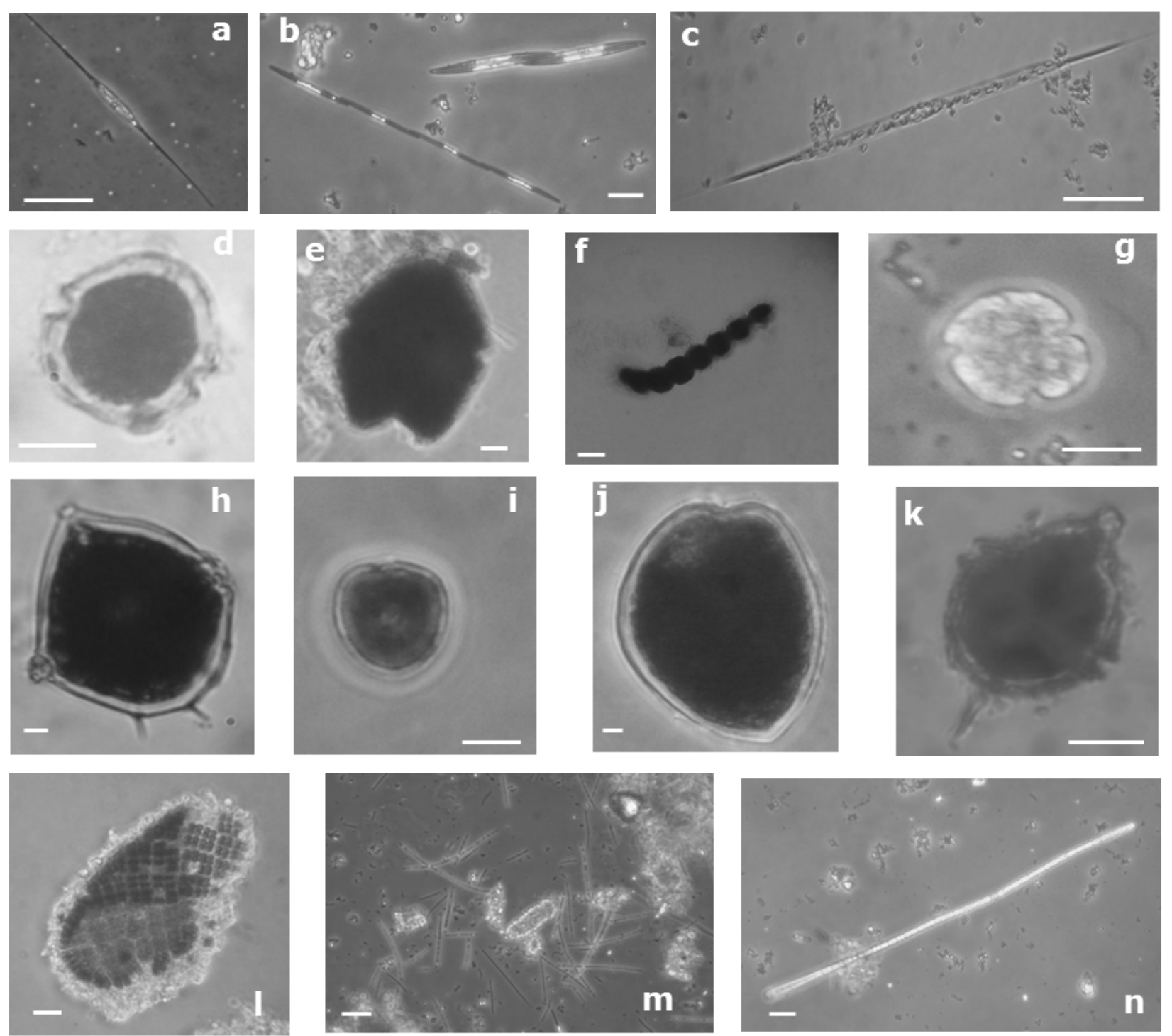

Figure 3. Photomicrographs of potentially harmful diatoms, dinoflagellates and cyanobacteria in oyster beds of Términos Lagoon, Campeche, Mexico (bright-field optics): a) Cylindrotheca closterium, b) Pseudo-nitzschia cf. americana and P. cf. seriata, c) Rhizosolenia setigera, d) Alexandrium sp., e) Akashiwo sanguinea, f) Gymnodinium cf. catenatum, g) Karenia cf. mikimotoi, h) Peridinium quinquecorne, i) Prorocentrum minimum, j) Prorocentrum mexicanum, k) Pyrodinium bahamense var. bahamense, l) Merismopedia sp., m) Cylindrospermopsis cuspis, $n$ ) Anabaena sp. Scale bar $=\mathbf{1 0} \boldsymbol{\mu m} /$ Microfotografías de diatomeas, dinoflagelados y cianobacterias potencialmente nocivos en los bancos ostrícolas de la laguna de Términos, Campeche, México (óptica de campo claro): a) Cylindrotheca closterium, b) Pseudo-nitzschia cf. americana and P. cf. seriata, c) Rhizosolenia setigera, d) Alexandrium sp., e) Akashiwo sanguinea, f) Gymnodinium cf. catenatum, g) Karenia cf. mikimotoi, h) Peridinium quinquecorne, i) Prorocentrum minimum, j) Prorocentrum mexicanum, k) Pyrodinium bahamense var. bahamense, I) Merismopedia sp., m) Cylindrospermopsis cuspis, n) Anabaena sp. Escala de la barra $=10 \mu \mathrm{m}$ 
important component of the phytoplankton community, the following potentially toxic dinoflagellates were present: Akashiwo sanguinea, Karenia cf. mikimotoi, Pyrodinium bahamense var. bahamense, Prorocentrum mexicanum and $P$. minimum (see Table 2).

Cyanobacterial abundance increased by orders of magnitude to $10^{6}$ cells $\mathrm{L}^{-1}$ in the windy season (October) and small peaks were also observed in the dry and rainy seasons (Fig. 2). Among cyanobacteria, the genus Anabaena Bory de Saint-Vincent was present throughout the study period, with a maximum abundance of $1.9 \times 10^{6}$ cells $\mathrm{L}^{-1}$ and a minimum abundance of $3.6 \times 10^{4}$ cells $\mathrm{L}^{-1}$ (Table 2, Fig. 3n). Merismopedia sp. and Oscillatoria sp. showed high abundances of $1.0 \times 10^{5}$ and $2.5 \times 10^{5}$ cells $\mathrm{L}^{-1}$, respectively, in the windy season (Table 2, Fig. 31) During the windy season, a bloom of Cylindrospermopsis cuspis was recorded with $1.3 \times 10^{6}$ cells $\mathrm{L}^{-1}$, and it lasted throughout the season with an abundance of up to $2.4 \times 10^{3}$ cells $\mathrm{L}^{-1}$ (Table 2, Fig. 3m).

\section{Relationship BetWeEN Physical-ChEMical PARAMETERS AND PHYTOPLANKTON}

The effect of the set of physical-chemical variables on phytoplankton species composition was tested using canonical correspondence analysis (CCA). As indicated by the CCA, the response of the species to physicalchemical variables was primarily explained by the first three axes (67.1\%; Table 3). The correlation between species and physical-chemical variables was low $(\mathrm{r} \sim 0.5)$, indicating an insignificant relationship between taxa and the physical-chemical variables used in the analysis. In the CCA, all canonical axes were not statistically significant $(P>0.05$, Monte Carlo). This means that the community phytoplankton structure cannot be explained, at least, for the studied period, by the environmental parameters evaluated.

\section{Discussion}

\section{Physical-chemical variables}

The water temperature variation observed during the study period is in accordance with the values reported by Robadue et al. (2004) and Yáñez-Arancibia \& Day (2005) for Términos Lagoon during at least 50 years, which, in general, is characteristic of a subtropical marine environment. The registered salinity range, which varied depending on the season, was accentuated in the rainy season. According to Ramos-Miranda et al. (2006), this reflects the seasonal change in insolation. In turn, it results in greater evaporation and hence a higher concentration of salts in the months before the start of the rainy season. At this time, the high freshwater input by rainfall and/or water discharges would inundate the entire lagoon, inducing a marked salinity gradient (Hernández-Guevara et al. 2008), coinciding with that observed during the study period. The values of $\mathrm{pH}$ and oxygen saturation suggested the activity of primary producers in the water column, resulting in changes in water quality (especially in $\mathrm{pH}$ and dissolved oxygen) as reported by Martínez-López et al. (2006), Poot-Delgado (2006), Hakspiel-Segura (2009) and Escobedo-Urías (2010) for the lagoons of the northwestern Mexican Pacific. The

Table 3. Eigenvalues and percentage of total variance explained by temporal canonical correspondence analysis of the oyster beds of Términos Lagoon, Campeche, Mexico, in 20122013 / Eigenvalores y porcentaje de la varianza total explicada por el análisis de correspondencia canónica temporal de los bancos ostrícolas de la laguna de Términos, Campeche, México, en 2012-2013

\begin{tabular}{cccc}
\hline Axes & Eigenvalue & $\begin{array}{c}\text { Species- } \\
\text { environment } \\
\text { correlations }\end{array}$ & $\begin{array}{c}\text { Cumulative } \\
\text { percentage } \\
\text { variance }\end{array}$ \\
\hline 1 & 0.025 & 0.476 & 29.8 \\
2 & 0.017 & 0.523 & 50.5 \\
3 & 0.014 & 0.431 & 67.1 \\
4 & 0.011 & 0.399 & 79.9 \\
\hline Test of significance of first canonical axes & F-ratio= 2.025 & P-value $=0.850$ \\
Test of significance of all canonical axes & F-ratio=0.813 & P-value $=0.916$ \\
\hline
\end{tabular}


average values observed for nitrite, nitrate and ammonium recorded in different seasons are well below the values reported by Contreras-Espinoza et al. (1996), HerreraSilveira et al. (2002) and Ramos-Miranda et al. (2006) for the southern Gulf of Mexico; however, the same pattern of high values recorded in the rainy season, coupled with the proximity of river mouths with strong freshwater influence, can be seen (Yáñez-Arancibia \& Day 2005, Ramos-Miranda et al. 2006). High values of orthophosphate and silicate are associated with the period of increased river discharge determined by circulation and biogeochemical processes (Botello \& Mandelli 1975, Ramos-Miranda et al. 2006).

These are variables that are linked to the period of high river discharge by rainfall enriching the waters at the entrance by new nutrients and causing high turbidity and low salinity (Yáñez-Arancibia \& Day 2005).

\section{COMMUNITY COMPOSITION OF PHYTOPLANKTON}

Being a body of shallow water, generally, no vertical stratification was found in the lagoon, so the wind and tidal currents probably keep the water well-mixed and allow a greater aeration of the water column (MagañaÁlvarez 2004)

Contributing to changes in phytoplankton composition and abundance, nanoflagellates and diatoms $<20 \mu \mathrm{m}$ presented their highest abundances, on the order of $10^{6}$ cells $\mathrm{L}^{-1}$, in the rainy season. These groups are likely to benefit from the high temperatures $\left(30.2^{\circ} \mathrm{C}\right)$; the relatively low salinity of 13.2 was most likely linked to the period of increased river discharge by rainfall (Yáñez-Arancibia \& Day 2005).

Phytoplankton responds quickly to environmental changes (Biswas et al. 2010). Thus, the highest abundances of diatoms $>20 \mu \mathrm{m}$ were observed in the dry season characterized by relatively high salinities (17.419.5) and an average temperature of $28^{\circ} \mathrm{C}$. Phytoplankton associations were characterized by the predominance of nanoflagellates and diatoms.

This situation was somewhat in contrast to data from the offshore region of the Bay of Campeche where the coccolithophores and nanoplanktonic diatoms numerically dominated the phytoplankton community in the dry season in April 2000 (Hernández-Becerril et al. 2008). In the tropical waters of the western Indian Ocean, the contribution of coccolithophores to total phytoplankton abundance is also important (Sá et al.
2013). In the present study, coccolithophores were observed only once in winter $\left(1000\right.$ cells $\left.\mathrm{L}^{-1}\right)$. They are known to prefer the nutrient-poor conditions and often thrive in areas where their competitors are starving (Weier 1999). Furthermore, in the southern Gulf of Mexico, including the offshore area in front of Términos Lagoon, maximum abundances of coccolithophores were observed in the subsurface (deeper than 10-30 m) layer (HernándezBecerril et al. 2008). However, both studies in the offshore area and in the coastal lagoon, respectively, showed the importance of nanoplankton, at least in terms of cell abundance. This was also recently confirmed for the Gulf of California where phytoplankton abundance was dominated both temporally and spatially by nanoplankton (Verdugo-Díaz et al. 2012). Furthermore, the dominance of chlorophytes $<10 \mu \mathrm{m}$ as one of the most abundant taxa among flagellates and in general in natural samples was also observed at Puerto Morelos in the Mexican Caribbean (Halac et al. 2013). Modern techniques such as HPLC pigment analysis applied recently to the studies of the taxonomic composition of tropical phytoplankton, apart from the groups mentioned above, also suggest the presence of at least some of the following taxonomic groups: Prochlorococcus sp., euglenophytes, prasinophytes, chrysophytes, prymnesiophytes and cryptophytes (Sá et al. 2013).

The presence of potentially harmful species reduces the percentage of oxygen saturation by an extraordinary increase in the number of phytoplankton cells, secondary metabolites and by the plugging of gills by highly silicified planktonic diatoms and silicoflagellates (Smayda 1997, Band-Schmidt et al. 2011). This can cause different responses in the life cycle of oysters: for example, Alexandrium taylori Balech produced mortality in larvae of Crassostrea gigas Thunberg in experimental exposure (Matsuyama et al. 2000).

The experimental exposure to toxic Alexandrium tamarense (Lebour) Balech produced mortalities in the bivalves Crassostrea virginica, Ostrea edulis Linnaeus (Lesser \& Shumway 1993) and Mytilus edulis Linnaeus (Shumway \& Cucci 1987). Alexandrium minutum Halim produced mortalities in juveniles and adults of Mytilus edulis and M. galloprovincialis Lamarck (Gainey \& Shumway 1988).

Some phytoplankters have structural features that may adversely affect other marine species. They are characterized by having a silicic frustule that is not only very strong, but also often provided with projections, 
spines or setae that can dig or tear the animal soft tissues. The frustules of Chaetoceros convolutus Castrac. and C. concavicornis Mangin possess setae or extensions that are covered with fine spinules that can damage gills of various fish species (Horner et al. 1990).

The CCA did not reveal an impact of nutrients on changes in the composition of the phytoplankton community. Along with the statistically insignificant correlation, our results demonstrate that the nutrients in general reflected the residence time of water in the lagoon, which in turn depends on the nature of the inputs that connect the lakes with the ocean (Pospelova et al. 2004). For Términos Lagoon, a nonlinear relationship between the concentration of nutrients and phytoplankton abundance was observed; this can be explained on the basis of the residence time of water in the lagoon. According to Yáñez-Arancibia \& Day (2005), the residence time is one month during the rainy season, 22 days during the windy season and almost 7 months during the dry season, unlike Alvarado Lagoon in the state of Veracruz in the southern Gulf of Mexico, where the primary production is controlled by the temperature and salinity (De la Lanza-Espino \& Lozano-Montes 1999). This difference was attributed to the residence time of the water, which is consistent with our suggestion.

This situation was observed by Varona-Cordero et al. (2010) for the coastal tropical lagoons Carretas-Pereyra and Chantuto-Panzacola in the southeastern Mexican Pacific, where the phytoplankton species composition during each season was dominated by different groups of species, which most likely allows the community to adapt to changes in resources and the physical-chemical environment.

Physical-chemical parameters such as temperature and salinity can determine the distribution or the occurrence of HABs, coupled with the availability of nutrients that regulate the growth rate, biomass and duration of bloom (Vargo 2009).

A possible link between nutrient enrichment of anthropogenic origin and increasing frequency of HAB events has not been rigorously tested, although there is growing evidence in favor of this from other parts of the world (Montresor \& Smetacek 2002). As understanding of the factors governing the competitive ability of different phytoplankton species increases, greater comprehension of the dynamics of microalgal blooms in this region will be obtained.

\section{ACKNOWLEDGMENTS}

We thank Sergio Poot-Delgado and Juan C. LiraHernández for providing support in the field, Martin Memije-Canepa for laboratory analyses of water samples, and Fausto R. Tafoya del Ángel and Leiver VazquezMedina for institutional coordination. We also thank Marcia M. Gowing from the Institute of Marine Sciences, University of California at Santa Cruz, California, who kindly improved the writing style. The financial support given to JRO to FOMIX-CONACYT-Campeche State Government project «Determinación del estado sanitario de los complejos ostricolas del municipio del Carmen» (2012-2014) is much appreciated. Anonymous reviewers kindly improved the manuscript.

\section{LITERATURE CITED}

Anderson DM, P Andersen, VM Bricelj, JJ Cullen \& JE Rensel. 2001. Monitoring and management strategies for harmful algal blooms in coastal waters. Technical Series 59: 1-268. Asia Pacific Economic Program, Singapore, and Intergovernmental Oceanographic Commission, Paris.

Anderson D, P Glibert \& J Burkholder. 2002. Harmful algal blooms and eutrophication: Nutrient sources, composition, and consequences. Estuaries 25: 704-726.

Bach L, R Calderon, MF Cepeda, A Oczkowski, SB Olsen \& D Robadue. 2005. Resumen del perfil de primer nivel del sitio laguna de Términos y su cuenca, México. Coastal Resources Center, 30 pp. University of Rhode Island, Narragansett.

Band-Schmidt CJ, JJ Bustillos-Guzmán, DJ López-Cortés, E Núñez-Vázquez \& FE Hernández-Sandoval. 2011. El estado actual del estudio de florecimientos algales nocivos en México. Hidrobiológica 21(3): 381-413.

Barreiro-Güemes MT \& A Aguirre-León. 1999. Distribución espacio-temporal de la biomasa fitoplanctónica en el sistema lagunar Pom-Atasta, Campeche, México. Revista de Biología Tropical 47(1): 27-35.

Biswas H, M Dey, D Ganguly, T De, S Ghosh \& T Jana. 2010. Comparative analysis of phytoplankton composition and abundance over a two-decade period at the land-ocean boundary of a tropical mangrove ecosystem. Estuaries and Coasts 33: 384-394.

Botello AV \& EF Mandelli. 1975. A study of variables related to the water quality of Terminos Lagoon and adjacent coastal areas, Campeche, Mexico. Final Report Project GU853, CCML, Universidad Nacional Autónoma de México, México, 92 pp.

Contreras-Espinoza F, O Castañeda-López, R TorresAlvarado \& F Gutiérrez. 1996. Nutrientes en 39 lagunas costeras mexicanas. Revista de Biología Tropical 44(2): 417 425 . 
Daniel WW. 1993. Bioestadística. Base para el análisis de las ciencias de la salud, 667 pp. Limusa, México.

De la Lanza-Espino G \& H Lozano-Montes. 1999. Comparación fisicoquímica de las lagunas de Alvarado y Términos. Hidrobiológica 9(1): 15-30.

Escobedo-Urías D. 2010. Diagnóstico y descripción del proceso de eutrofización en lagunas costeras del norte de Sinaloa, Tesis Doctoral, Centro Interdisciplinario de Ciencias Marinas-Instituto Politécnico Nacional, La Paz, 298 pp.

Gainey LF Jr \& SE Shumway. 1988. A compendium of the responses of bivalve molluscs to toxic dinoflagellates. Journal of Shellfish Research 7: 623-628.

García-Ríos V, L Alpuche-Gual, J Herrera-Silveira, J Montero-Muñoz, S Morales-Ojeda, D Pech, MF Cepeda-González, O Zapata-Pérez \& G Gold-Bouchot. 2013. Towards a coastal condition assessment and monitoring of the Gulf of Mexico Large Marine Ecosystem (GoM LME): Terminos Lagoon pilot site. Environmental Development 7: 72-79.

Garson D. 2012. Testing statistical assumptions, 52 pp. Statistical Associates Publishing, Asheboro. < http:// www.statisticalassociates.com/assumptions.pdf>

GEOHAB. 2006. Global ecology and oceanography of harmful algal blooms. In: Glibert P (ed). Harmful algal blooms in eutrophic systems, 74 pp. IOC / SCOR, Paris / Baltimore.

Glibert P, D Anderson, P Gentien, E Graneli \& K Sellner. 2005. The global, complex phenomena of harmful algal blooms. Oceanography 18: 130-141.

Glibert PM, CA Heil, JM O'Neil, C William, I Dennison \& MJH O'Donohue. 2006. Nitrogen, phosphorus, silica, and carbon in Moreton Bay, Queensland, Australia: differential limitation of phytoplankton biomass and production. Estuaries and Coasts 29(2): 209-221.

Grzebyk D, A Denardou, B Berland \& YF Pouchus. 1997. Evidence of a new toxin in the red-tide dinoflagellate Prorocentrum minimum. Journal of Plankton Research 19: 1111-1124.

Gómez-Aguirre S. 1974. Reconocimientos estacionales de hidrología y plancton en la laguna de Términos Campeche, México. Anales del Instituto de Ciencias del Mar y Limnología 1(1): 61-82.

Hakspiel-Segura C. 2009. Variación estacional de la trama trófica microbiana en la laguna de Macapule, Sinaloa, Tesis de Maestría, Centro Interdisciplinario de Ciencias MarinasInstituto Politécnico Nacional, La Paz, 189 pp.

Halac SR, SD Guendulain-García, VE Villafañe, EW Helbling \& AT Banaszak. 2013. Responses of tropical plankton communities from the Mexican Caribbean to solar ultraviolet radiation exposure and increased temperature. Journal of Experimental Marine Biology and Ecology 445: 99-107.

Hallegraeff GM. 2002. Aquaculturist's guide to harmful Australian microalgae, $136 \mathrm{pp}$. School of Plant Science, University of Tasmania, Hobart.
Hallegraeff GM, DM Anderson, AD Cembella \& HO Enevoldsen. 2003. Manual on harmful marine microalgae. Monographs on Oceanographic Methodology 11: 1-793. IOC-UNESCO, Paris.

Hernández-Becerril DU, JA García-Reséndiz, DA Salasde León, MA Monreal-Gómez, M Signoret-Poillon \& J Aldecio-Ramírez. 2008. Nanoplankton fraction in the phytoplankton structure in the southern Gulf of Mexico (April 2000). Ciencias Marinas 34(1): 77-90.

Hernández-Guevara NA, PL Ardisson \& D Pech. 2008. Temporal trends in benthic macrofauna composition in response to seasonal variation in a tropical coastal lagoon, Celestun, Gulf of Mexico. Marine and Freshwater Research 59: 772-779.

Herrera-Silveira JA, R Silva-Casarín, PS Alfonso de Almeida, GJ Villalobos-Zapata, I Medina-Gómez, JC Espinal-González, A Zaldívar-Jiménez, J Trejo-Peña, M González-Jáuregui, A Cú-Escamilla \& J RamírezRamírez. 2002. Análisis de la calidad ambiental usando indicadores hidrobiológicos y modelo hidrodinámico actualizado de laguna de Términos, Campeche, 187 pp. Informe Técnico, CINVESTAV-Mérida, EPOMEXCampeche, UNAM-México.

Horner RA, JA Postel \& JE Rensel. 1990. Noxious phytoplankton blooms in Western Washington waters. A review, In: Granéli E, B Sundstrom, L Edler \& DM Anderson (eds). Toxic marine phytoplankton, pp. 171-176. Elsevier, New York.

IOC. 2002. IOC Taxonomic reference list of toxic algae. Intergovernmental Oceanographic Commission of UNESCO, Paris. < http://www.marinespecies.org/hab/>

Kudela RM, JQ Lane \& WP Cochlan. 2008. The potential role of anthropogenically derived nitrogen in the growth of harmful algae in California, USA. Harmful Algae 8: 103110.

Landsberg J, S Hall, JN Johannessen, KD White, SM Conrad, J Abbot, LJ Flewelling, WR Richardson, RW Dickey, ELE Jester, SM Etheridge, JR Deeds, FM Van Dolah, TA Leighfield, Y Zou, CG Beaudry, RA Benner, PL Rogers, PS Scott, K Kawabata, JL Wolny \& KA Steidinger. 2006. Saxitoxin puffer fish poisoning in the United States, with the first report of Pyrodinium bahamense as the putative toxin source. Environmental Health Perspective 114(10): 1502-1507.

Lesser MP \& SE Shumway. 1993. Effects of toxic dinoflagellates on clearance rates and survival in juvenile bivalve molluscs. Journal of Shellfish Research 12: 377 381.

Lindahl O. 1986. A dividable hose for phytoplankton sampling. In: Report of the working group on phytoplankton and management of their effects. International Council for the Exploration of the Sea, C.M. 1986/L: 26, Annex 3: 1-3. Copenhagen. 
Magaña-Álvarez M. 2004. Distribución de nutrientes y su efecto en el nivel trófico de la laguna de Macapule, Sinaloa. Tesis de Maestría, Centro Interdisciplinario de Investigación para el Desarrollo Integral Regional, Instituto Politécnico Nacional, Guasave, 115 pp.

Martínez-López A, D Escobedo-Urías, AE Ulloa-Pérez \& C Band-Schmidt. 2006. Bloom of Chattonella subsalsa in a eutrophic coastal lagoon in the Gulf of California. Harmful Algae News 31(1): 4-5.

Matsuyama Y, H Usuki, T Uchida \& Y Kotani. 2000. Effects of harmful algae on the early planktonic larvae of oyster, Crassostrea gigas, In: Hallegraeff GM, SI Blackburn, CJ Bolch \& RJ Lewis (eds). Proceedings of the Ninth International Conference on Harmful Algal Blooms, pp. 411-414. Intergovernmental Oceanographic Commission of UNESCO, Paris.

Montresor M \& V Smetacek. 2002. The impact of harmful algal blooms in natural and human-modified systems of Northern Europe. In: Werfer G, W Berger, KE Behre \& E Jansen (eds). Climate development and history of the North Atlantic realm, pp. 457-471. Springer-Verlag, Berlin.

Muciño-Márquez RE, MG Figueroa-Torres \& A AguirreLeón. 2014. Composición fitoplanctónica en los sistemas fluvio-lagunares Pom-Atasta y Palizada del Este, adyacentes a la laguna de Términos Campeche, México. Acta Biológica Colombiana 19(1): 63-84.

Núñez-Vázquez EJ, I Gárate-Lizárraga, CJ Band-Schmidt, A Cordero-Tapia, DJ López-Cortés, FE HernándezSandoval, A Heredia-Tapia \& JJ Bustillos-Guzmán. 2011. Impact of harmful algal blooms on wild and culture, animals in the Gulf of the California. Journal of Environmental Biology 32(4): 407-412.

Phlips EJ \& S Badylak. 2012. Phytoplankton abundance and composition in the Indian River Lagoon 2011-2012. Annual Report. Fisheries and Aquatic Sciences/S.F.R.C., University of Florida. Gainesville, $31 \mathrm{pp}$.

Poot-Delgado C. 2006. Estructura de la comunidad fitoplanctónica con énfasis en las especies tóxicas y/o nocivas de la laguna de Macapule, Sinaloa. Tesis de Maestría, Centro Interdisciplinario de Ciencias Marinas, Instituto Politécnico Nacional, La Paz, 142 pp.

Poot-Delgado CA, YB Okolodkov, JA Aké-Castillo \& J Rendón-von Ostén. 2013. Microalgas potencialmente nocivas en bancos ostrícolas de la laguna de Términos, Golfo de México. En: Memorias del XX Congreso Nacional de Ciencia y Tecnología del Mar, 1 al 5 de octubre del 2013, Los Cabos, México, 10 pp.

Pospelova V, GL Chumura \& HA Wlaker. 2004. Environmental factors influencing the spatial distribution of dinoflagellate cyst assemblages in shallow lagoons of southern New England (USA). Review of Paleobotany and Palynology 128: 7-34.
Ramos-Miranda J, D Flores-Hernández, LA Ayala-Pérez, J Rendón-von Osten, G Villalobos-Zapata \& A SosaLópez. 2006. Atlas hidrológico e ictiológico de la laguna de Términos, 173 pp. Universidad Autónoma de Campeche, Campeche.

Robadue D, A Oczkowski, R Calderon, L Bach \& MF Cepeda. 2004. Characterization of the region of the Terminos Lagoon, Campeche, Mexico: Draft for discussion, 51 pp. The Nature Conservancy Coastal Resources Center, University of Rhode Island, Narragansett.

Rojas-Galavíz JL, F Vera-Herrera, A Yáñez-Arancibia \& JW Day. 1990. Ecosystem dynamics of the Palizada river delta, México: The role of the dual riverine/tidal subsidy in a tropical tidal freshwater environment. Estuaries 42(3): 663-672.

Sá C, MC Leal, A Silva, S Nordez, E André, J Paula \& V Brotas. 2013. Variation of phytoplankton assemblages along the Mozambique coast as revealed by HPLC and microscopy. Journal of Sea Research 79: 1-11.

Shumway SE \& TL Cucci. 1987. The effects of the toxic dinoflagellate Protogonyaulax tamarensis on the feeding and behavior of bivalve molluscs. Aquatic Toxicology 10: 9-27.

Smayda TJ. 1997. What is a bloom? A commentary. Limnology and Oceanography 42: 1132-1136.

Smayda TJ. 2002. Adaptative ecology, growth strategies and the global bloom expansion of dinoflagellates. Journal of Oceanography 58: 281-294.

Strickland JD \& TR Parsons. 1972. A practical handbook for the sea water analysis. Bulletin of the Fisheries Research Board of Canada 167: 1-310.

Suárez-Caabro JA \& S Gómez-Aguirre. 1965. Observaciones sobre el plancton de la Laguna de Términos, Campeche, México. Bulletin of Marine Science 15: 10721120.

Ter Braak CJF. 1986. Canonical correspondence analysis: a new eigenvector technique for multivariate direct gradient analysis. Ecology 67: 1167-1179.

Throndsen J. 1978. Preservation and storage, In: Sournia A (ed). Phytoplankton manual. UNESCO Monographs on Oceanographic Methodology 6: 69-74. UNESCO, Paris.

UNESCO. 2009. Cianobacterias planctónicas del Uruguay. In: Bonilla S (ed). Manual para la identificación y medidas de gestión. Documento Técnico PHI 16: 1-105, Programa Hidrológico Internacional para América Latina y el Caribe (PHI-LAC), Oficina Regional de Ciencia para América Latina y el Caribe, UNESCO, Montevideo.

Utermöhl H. 1958. Zur vervolkommung der quantitative. Phytoplankton-Methodik. Internationale Vereiningung fuer Theoretische und Angewandte Limnologie 9: 1-38. 
Vargo G. 2009. A brief summary of the physiology and ecology of Karenia brevis Davis (G. Hansen and Moestrup comb. nov.). Red tides on the West Florida Shelf and of hypotheses posed for their initiation, growth, maintenance, and termination. Harmful Algae 8: 573-584.

Varona-Cordero F, FJ Gutiérrez-Mendieta \& ME Meave del Castillo. 2010. Phytoplankton assemblages in two compartmentalized coastal tropical lagoons (CarretasPereyra and Chantuto-Panzacola, Mexico). Journal of Plankton Research 32(9): 1283-1299.

Verdugo-Díaz G, A Martínez-López, G Gaxiola-Castro \& JE Valdez-Holguín. 2012. Phytoplankton photosynthetic parameters from the Gulf of California southern region. Revista de Biología Marina y Oceanografía 47(3): 527-535.
Weier J. 1999. Coccolithophores are one-celled marine plants. NASA Earth Observatory, EOS Project Science Office, NASA's Goddard Space Flight Center, Greenbelt, Maryland, USA, April 29, 1999. <http:// earthobservatory.nasa.gov/Features/Coccolithophores>

Yáñez-Arancibia A \& JW Day. 1988. Ecology of coastal ecosystems in the Southern Gulf of Mexico: The Terminos Lagoon region, 518 pp. Organization of American States Washington DC, Louisiana State University Baton Rouge, USA, UNAM Press, Mexico.

Yáñez-Arancibia A \& JW Day. 2005. Ecosystem functioning: the basis for sustainable management of Terminos Lagoon, Campeche, México, 77 pp. Institute of Ecology A.C., Jalapa.

Received 15 October 2014 and accepted 19 June 2015

Editor: Claudia Bustos D. 